\title{
Effect of Different Sowing Dates and Cultivars on Growth and Productivity of Mungbean Crop
}

\author{
Maqsood Ahmad ${ }^{1}$, Muhammad Umer Chattha ${ }^{1}$, Imran Khan ${ }^{1}$, Muhammad Bilal Chattha ${ }^{2 *}$, Faqir Hussain \\ Anjum $^{3}$, Sadia Afzal ${ }^{4}$, Muhammad Faran', Fiaz Hussain ${ }^{3}$, Muhammad Talha Aslam ${ }^{1}$, Abdul Jabbar, \\ Muhammad Sultan Ali Bazmi ${ }^{5}$, Mahnoor Mehmood ${ }^{6}$ and Muhammad Umair Hassan'
}

${ }^{1}$ Department of Agronomy, University of Agriculture, Faisalabad, 38040, Pakistan; ${ }^{2}$ Institute of Agricultural Sciences, University of the Punjab, Lahore, Pakistan; ${ }^{3}$ Directorate of Agronomy, Ayub Agricultural Research Institute, Faisalabad, Pakistan; ${ }^{4}$ Department of Chemistry, University of Agriculture, Faisalabad, 38040, Pakistan; ${ }^{5}$ Fodder Research Institute Sargodha, Pakistan; ${ }^{6}$ Department of Botany, University of Agriculture, Faisalabad, Pakistan.

\begin{tabular}{|c|}
\hline $\begin{array}{l}\text { wth } \\
\text { rree } \\
\text { d of } \\
\text { ng- } \\
\text { lant } \\
25^{\text {th }} \\
.22 \\
\text { ars, } \\
\text { m), } \\
\text { had } \\
\text { and } \\
\text { um } \\
\text { CS }\end{array}$ \\
\hline
\end{tabular}

\section{Introduction}

L egume grains provide food for humans and feed for livestock, along with providing these benefits legume crops also improve soil fertility (Baddeley et al., 2013). Mungbean (Vigna radiate) being a leguminous crop can replenish soil fertility and avert land degradation and improves crop production and livestock rearing while sustaining the ecosystem (Chattha et al., 2017a). Cultivation of such dualpurpose leguminous crops enhances the overall productivity of the agricultural system and conserves 
the natural resources and helps for gaining more output from the agricultural system (Kassie, 2011).

The rice-wheat cropping system (RWCS) is a vital system globally especially in South Asia where it provides the most of the grains for consumption to meet the daily dietary needs (Timsina and Connor, 2001). As for the growing population, this system suits best producing cereals in a year to fulfill the demands of the mushrooming population. As the sustainability of this system depends upon the efficient usage of the nutrients, thus it is demanded to develop and implement soil managing techniques that would enhance the soil organic matter along with increasing the activity of the microbes and retain the productivity of the soils in a sustainable way (Ali et al., 2012). The inclusion of legumes as green manure crops in prevailing RWCS can enhance soil fertility in a sustainable manner (Ali et al., 2012).

Among different reasons for the lower production of pulses in Pakistan, seeding time and plant population have special importance. In the changing scenario of different abiotic and biotic stress, the managerial practices must be optimized for ensuring the better crop production (Hassan et al., 2020a, b). Agro-ecological conditions play a vital role in the determination of planting time. Similarly, optimum sowing time in mungbean may vary from variety to variety (Sarkar et al., 2004). Planting time is of paramount importance and it has a significant effect on growth, development and yield (Asghar et al.,2006; Aslam et al., 2015; Hassan et al., 2020c; Mohsin et al., 2021). The planting time significantly varies among cultivars, therefore proper planting times should be adopted in order to get higher productivity (Aslam et al., 2000).

The early sowing enhances final yield and biomass production owing to an increase in grain weight and other production traits (Barros et al., 2004; Hassan et al., 2020). The decrease in the growth cycle due to late sowing reduced the interception of radiations that decreases the accumulation of total dry matter and consequently leads to poor yield (Vega and Hall, 2002). Selection of the cultivar and appropriate sowing date is very essential to attain yield (Jan et al., 2002). Various varieties of mungbean respond differently to sowing dates and growing season. Thus, for different varieties of mungbean there should be varied optimum sowing dates (Reddy, 2009). After identifying high yielding cultivars, sowing at optimum dates can result in higher yields (Ali and Gupta, 2012). The variable authors reported the significant differences in the seed yield of mungbean with variable planting times. The sowing of the crop from $15^{\text {th }}$ April to $15^{\text {th }}$ May produced the maximum yield compared to crop sown before $15^{\text {th }}$ April and after $15^{\text {th }}$ May (Yan-sheng et al., 2010). The late sowing after $15^{\text {th }}$ May results in less dry matter production, smaller pods with lower seeds, and poor yield as compared to sowing before $15^{\text {th }}$ May (Yoldas and Esiyok, 2007). We hypothesized that variable sowing dates and cultivars can have differential responses in terms of growth and seed production. Therefore, the study was conducted to determine the impact of cultivars and sowing times on the growth and productivity of mungbean crop grown in RWCS.

\section{Materials and Methods}

\subsection{Experimental site}

The current study was executed at Agronomic Research Area, University of Agriculture Faisalabad in 2018 to determine the potential of mungbean as a catch crop in RWCS. The experimental site has hot and humid semi-arid conditions (Chattha et al., 2019; Zamir et al., 2020) further prevailed weather conditions during the crop period are given below in Table 1 . The composite samples were collected with the help of a soil auger from a depth of 0-30 $\mathrm{cm}$. The soil was tested according to the procedure of Homer and Pratt (1961). The soil was sandy loam with $\mathrm{pH} 7.84$, organic matter $0.84 \%$, available nitrogen $0.041 \%$, available phosphorus $6.63 \mathrm{mg} \mathrm{kg}^{-1}$, and available potassium $179 \mathrm{mg} \mathrm{kg}^{-1}$.

$\begin{aligned} & \text { Table 1: The climatic conditions during the study } \\
& \text { period. }\end{aligned}$
\begin{tabular}{llll}
\hline Months & $\begin{array}{l}\text { Monthly average } \\
\text { temperature }\left({ }^{\circ} \mathbf{C}\right)\end{array}$ & $\begin{array}{l}\text { Rainfall } \\
(\mathbf{m m})\end{array}$ & $\begin{array}{l}\text { Relative } \\
\text { humidity (\%) }\end{array}$ \\
\hline April & 28.5 & 7.9 & 47.3 \\
May & 32.0 & 21.6 & 29.8 \\
June & 33.9 & 92.0 & 56.5 \\
July & 33.0 & 195.8 & 70.2 \\
\hline
\end{tabular}

\subsection{Experimental detail and crop husbandry}

The experiment was conducted using a net plot size of $15 \mathrm{~m}^{2}$ under randomized complete block design (RCBD) with a split plot arrangement having three replications. The study was comprised of mungbean cultivars; AZRI Mung-2006, NM-2011 and NM- 
2016 and different sowing dates; $25^{\text {th }}$ April, $5^{\text {th }}$ May and $15^{\text {th }}$ May. The soil was pulverized with cultivation followed by planking to prepare the fine seedbed. The mungbean crop was sown in $30 \mathrm{~cm}$ apart rows using the hand drill. Urea $(46 \% \mathrm{~N})$, di-ammonium phosphate $(46 \% \mathrm{P}, 18 \% \mathrm{~N})$ and sulphate of potash $(50 \% \mathrm{~K})$ were used to apply recommended dose of NPK@ 20:40:40 per hectare. The full dose of $\mathrm{P}$ and $\mathrm{K}$ and half of $\mathrm{N}$ was applied as basal dose and the remaining $\mathrm{N}$ was applied at first irrigation. All other agronomic practices were kept the same for getting optimum yield production.

\subsection{Observations}

In each plot, one square meter area was marked and both broad and narrow weeds were uprooted and weighed to determine their biomass 30 and 60 days after sowing (DAS) of mungbean crop. For the determination of leaf area one meter long row in each plot was harvested and a sub-sample $(10 \mathrm{~g})$ of leaves was taken and leaf area was measured by leaf area meter and leaf area index was measured by the method of Watson (1947). Moreover, leaf samples taken for determining leaf area were oven-dried and crop growth rate was determined by methods of Hunt (1978). Ten plants were marked in each plot, plant height was measured and pods were counted and averaged. Likewise, ten pods were taken and their length was measured and grains were counted from each pod and the average was worked out. Complete plots of each treatment were harvested and bundles were made and weighed to determine biological yield and threshed to determine seed yield and later converted into $\mathrm{tha}^{-1}$.

\subsection{Statistical analysis}

The observations on growth, yield and weed traits were analyzed by Fisher's analysis of variance technique (Steel et al., 1997). Furthermore, the differences among treatment means were compared by LSD test at a $5 \%$ level of probability.

\section{Results and Discussion}

\subsection{Weeds biomass}

The results indicated that sowing dates (SD) significantly affected broad and narrow leaves weed biomass however mungbean cultivars had a nonsignificant impact on weeds biomass (Table 2). The maximum broad and narrow leaves weeds biomass was noted in the crop sown on $15^{\text {th }}$ May, followed by the crop sown on the $5^{\text {th }}$ May and minimum broad and narrow weeds biomass was noted in crop sown on $25^{\text {th }}$ April (Table 2). The higher rainfalls in mid-May and the start of June reduced the seedling emergence of mungbean and provided the opportunity for weeds to emerge which resulted in higher weeds biomass in this sowing date. These results are the same with outcomes of Knezev et al. (2002) they also noticed more weed biomass in the later sown crops.

\subsection{Growth attributes}

The variables SD and cultivars had a significant impact on the leaf area index (LAI) and crop growth rate (Figures 1, 2). LAI and CGR increased over time and reached to maximum values at 60DAS, afterwards the LAI and CGR started declining. The maximum LAI and CGR were noticed in the crop sown on the $25^{\text {th }}$ April, and the lowest LAI and CGR were recorded in the crop sown on $15^{\text {th }}$ May. Amongst cultivars, NM-2006 had maximum LAI and CGR and lowest LAI and CGR were noticed for Azri-mung, 2006. After 60DAS both LAI and CGR started decreasing and minimum reduction in LAI and CGR was recorded from crop sown on $25^{\text {th }}$ April and in cultivar NM-2006 (Figures 1, 2). The early sown crop faced better climatic conditions during the life cycle, and it produced longer leaves with maximum width, therefore, had more leaf area. Likewise, in early sowing higher LAI resulted in maximum light-harvesting which favored higher dry matter production and consequently led to higher CGR in crop sown on $25^{\text {th }}$ April. Variations amid the cultivars for the LAI can be due the differences in the leaf length and leaf width. Cultivar NM-2006 had longer leaves therefore, had more LAI, likewise, higher LAI was responsible for the higher CGR in this cultivar compared to others. The earlier plating provides a longer growth period for the crops which ensures better light-harvesting and produced more assimilates therefore, had better LAI and CGR (Rao et al., 2012; Darany, 2016). Moreover, these outcomes are the same with the finding of Wiedenfeld and Matocha (2010), Hassan et al. (2018a, b) they also found differences amid cultivars for LAI and CGR.

\subsection{Yield and yield traits}

The results indicated that different SD and cultivars significantly affected plant height, pod length and pods/plant (Table 3). The maximum plant height $(52.67 \mathrm{~cm})$, pod length $(11.39 \mathrm{~cm})$, pods/plant $(22.11)$ and grains/pod (13.56) were noticed in crop sown on 
Table 2: Effect of different cultivars and sowing times on broad and narrow leaf weeds grown in mungbean crop.

\begin{tabular}{|c|c|c|c|c|}
\hline Cultivars & $\begin{array}{l}\text { Broad leaf weeds bio- } \\
\text { mass (g) } 30 \text { DAS }\end{array}$ & $\begin{array}{l}\text { Broad leaf weeds bio- } \\
\text { mass (g) } 60 \text { DAS }\end{array}$ & $\begin{array}{l}\text { Narrow leaf weeds } \\
\text { biomass (g) } 30 \text { DAS }\end{array}$ & $\begin{array}{l}\text { Narrow leaf weeds } \\
\text { biomass (g) } 60 \text { DAS }\end{array}$ \\
\hline Azri-Mung 2006 & 427.00 & 561.22 & 56.89 & 64.00 \\
\hline NM-2011 & 432.22 & 569.67 & 59.78 & 67.22 \\
\hline NM-2006 & 431.11 & 577.00 & 59.11 & 63.67 \\
\hline $\mathrm{LSD} \leq 0.05 \mathrm{P}$ & NS & NS & NS & NS \\
\hline \multicolumn{5}{|l|}{ Sowing dates (SD) } \\
\hline $25^{\text {th }}$ April & $392.11 \mathrm{C}$ & $469.11 \mathrm{C}$ & $47.22 \mathrm{C}$ & $57.22 \mathrm{~B}$ \\
\hline $5^{\text {th }}$ May & 415.11B & $580.22 \mathrm{~B}$ & $59.22 \mathrm{~B}$ & $68.00 \mathrm{~A}$ \\
\hline $15^{\text {th }}$ May & $483.11 \mathrm{~A}$ & $658.56 \mathrm{~A}$ & $69.33 \mathrm{~A}$ & $69.67 \mathrm{~A}$ \\
\hline $\mathrm{LSD} \leq 0.05 \mathrm{P}$ & 4.77 & 25.17 & 6.65 & 6.28 \\
\hline \multicolumn{5}{|l|}{ Cultivars $\times$ SD } \\
\hline Azri-Mung $2006 \times 25^{\text {th }}$ April & 391.67 & 456.33 & 45.00 & 55.00 \\
\hline NM-2011×25 $5^{\text {th }}$ April & 397.33 & 464.00 & 48.67 & 58.67 \\
\hline NM-2006 $\times 25^{\text {th }}$ April & 387.33 & 487.00 & 48.00 & 58.00 \\
\hline Azri-Mung $2006 \times 5^{\text {th }}$ May & 413.67 & 576.00 & 57.67 & 67.67 \\
\hline NM-2011 $\times 5^{\text {th }}$ May & 416.00 & 586.33 & 60.33 & 70.67 \\
\hline NM-2006×5 th $M a y$ & 415.67 & 578.33 & 59.67 & 65.67 \\
\hline Azri-Mung $2006 \times 15^{\text {th }}$ May & 475.67 & 651.33 & 68.00 & 69.33 \\
\hline NM-2011×15 & 483.33 & 658.67 & 70.33 & 72.33 \\
\hline 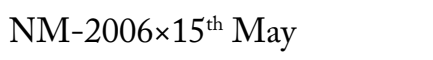 & 490.33 & 665.67 & 69.67 & 67.33 \\
\hline $\mathrm{LSD} \leq 0.05 \mathrm{P}$ & NS & NS & NS & NS \\
\hline
\end{tabular}

Means with different letters differed at $0.05 \mathrm{P}$ level. DAS: days after sowing.

Table 3: Effect of different cultivars and sowing times on yield traits of mungbean crop.

\begin{tabular}{|c|c|c|c|c|}
\hline Cultivars & Plant height (cm) & Pod length $(\mathrm{cm})$ & Pods per plant & Grains per pod \\
\hline Azri-Mung 2006 & $44.78 \mathrm{C}$ & $9.60 \mathrm{C}$ & $19.22 \mathrm{~B}$ & $10.56 \mathrm{C}$ \\
\hline NM-2011 & $48.22 \mathrm{~B}$ & $10.71 \mathrm{~B}$ & $20.11 \mathrm{~B}$ & $11.44 \mathrm{~B}$ \\
\hline NM-2006 & $50.56 \mathrm{~A}$ & $11.59 \mathrm{~A}$ & $21.56 \mathrm{~A}$ & $12.67 \mathrm{~A}$ \\
\hline $\mathrm{LSD} \leq 0.05 \mathrm{P}$ & 2.03 & 0.68 & 1.12 & 0.85 \\
\hline \multicolumn{5}{|l|}{ Sowing dates (SD) } \\
\hline $25^{\text {th }}$ April & $52.67 \mathrm{~A}$ & $11.39 \mathrm{~A}$ & $22.11 \mathrm{~A}$ & $13.56 \mathrm{~A}$ \\
\hline $5^{\text {th }}$ May & $47.22 \mathrm{~B}$ & $10.59 \mathrm{~B}$ & $20.44 \mathrm{~B}$ & 11.11B \\
\hline $15^{\text {th }}$ May & $43.67 \mathrm{C}$ & $9.92 \mathrm{C}$ & $18.33 \mathrm{C}$ & $10.00 \mathrm{~B}$ \\
\hline $\mathrm{LSD} \leq 0.05 \mathrm{P}$ & 2.12 & 0.23 & 1.56 & 1.15 \\
\hline \multicolumn{5}{|l|}{ Cultivars $\times$ SD } \\
\hline Azri-Mung $2006 \times 25^{\text {th }}$ April & 49.33 & $10.27 \mathrm{de}$ & $21.00 \mathrm{bc}$ & 12.33 \\
\hline 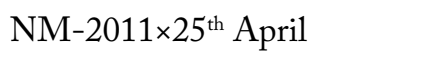 & 53.00 & $11.60 \mathrm{ab}$ & $21.33 \mathrm{~b}$ & 13.67 \\
\hline NM-2006 $\times 25^{\text {th }}$ April & 55.67 & $12.30 \mathrm{a}$ & $24.00 \mathrm{a}$ & 14.67 \\
\hline Azri-Mung $2006 \times 5^{\text {th }}$ May & 44.00 & $9.60 \mathrm{ef}$ & $19.00 \mathrm{~cd}$ & 9.67 \\
\hline NM-2011×5 $5^{\text {th }}$ May & 47.33 & 10.60cde & $20.67 \mathrm{bc}$ & 11.00 \\
\hline NM-2006×5 $5^{\text {th }}$ May & 50.33 & $11.57 \mathrm{abc}$ & $21.67 \mathrm{~b}$ & 12.67 \\
\hline Azri-Mung $2006 \times 15^{\text {th }}$ May & 41.00 & $8.93 \mathrm{f}$ & $17.67 \mathrm{~d}$ & 9.67 \\
\hline NM-2011×15 $5^{\text {th }}$ May & 44.33 & 9.93def & $18.33 \mathrm{~d}$ & 9.67 \\
\hline NM-2006×15 & 45.67 & $10.90 \mathrm{bcd}$ & $19.00 \mathrm{~cd}$ & 10.67 \\
\hline $\mathrm{LSD} \leq 0.05 \mathrm{P}$ & NS & 1.19 & 1.93 & NS \\
\hline \multicolumn{5}{|c|}{ Means with different letters differed at $0.05 \mathrm{P}$ level. } \\
\hline
\end{tabular}




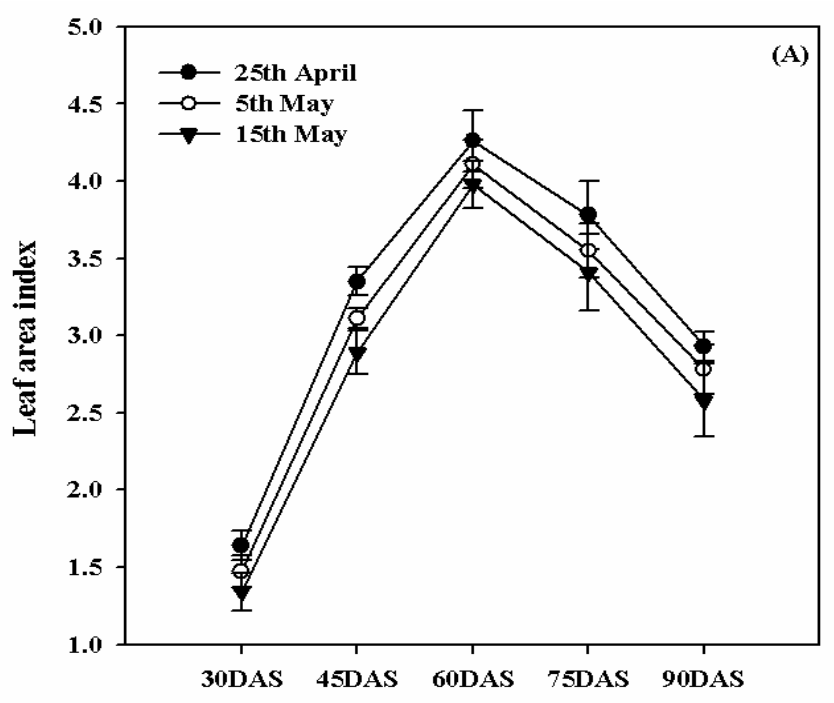

temperature and high rains during the flowering stages which led to smaller pods with less grains. The currents outcomes are similar with outcomes of Mondal (2004) they also noticed that early sown crop produced longer pods. The cultivars also behaved differently for the pod length, pods/plant and grains/ pod; the difference among the cultivars for the pod length, pods/plant and grains/pod can be described to differences in the genetic makeup (Chattha et al., 2017b; Hassan et al., 2019a, b).
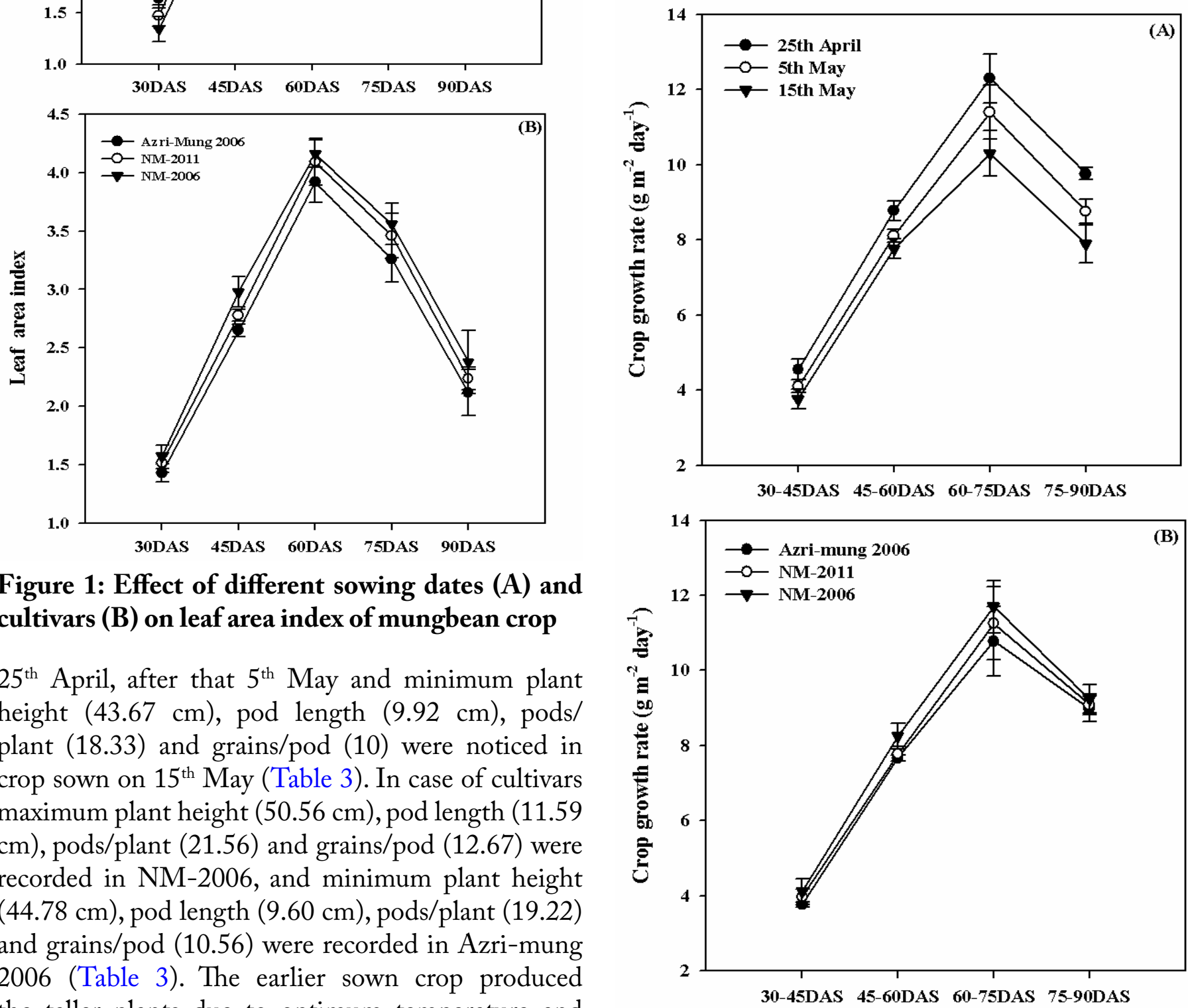

Figure 1: Effect of different sowing dates (A) and cultivars $(B)$ on leaf area index of mungbean crop

$25^{\text {th }}$ April, after that $5^{\text {th }}$ May and minimum plant height $(43.67 \mathrm{~cm})$, pod length $(9.92 \mathrm{~cm})$, pods/ plant (18.33) and grains/pod (10) were noticed in crop sown on $15^{\text {th }}$ May (Table 3 ). In case of cultivars maximum plant height $(50.56 \mathrm{~cm})$, pod length $(11.59$ $\mathrm{cm}$ ), pods/plant (21.56) and grains/pod (12.67) were recorded in NM-2006, and minimum plant height $(44.78 \mathrm{~cm})$, pod length $(9.60 \mathrm{~cm})$, pods/plant $(19.22)$ and grains/pod (10.56) were recorded in Azri-mung 2006 (Table 3). The earlier sown crop produced the taller plants due to optimum temperature and moisture conditions faced by the crop (Soomro, 2003). The cultivars also had significant impact on the plant height; cultivar NM-2006 produced the taller plant owing to vigorous growth as compared to other cultivars (Siddique et al., 2006). The earlier sown crop got the longer time period for the crop growth and development and produced more assimilates thus it resulted in production of longer pods with more grains. Moreover, crop sown on $15^{\text {th }}$ May faced higher

Figure 2: Effect of different sowing dates (A) and cultivars (B) on crop growth rate $\left(\mathrm{g} \mathrm{m}^{-2}\right.$ day $\left.^{-1}\right)$ of mungbean crop.

The variable $\mathrm{SD}$ and cultivars also significantly affected seed and biomass yield and harvest index. The maximum seed yield, biological yield and harvest index were noted in crop sown on $25^{\text {th }}$ April after that $5^{\text {th }}$ May and minimum seed and biological yield and 
harvest were recorded from crop sown on $15^{\text {th }}$ May (Table 4). Likewise, in the case of cultivars maximum seed and biological yield and harvest index were noticed in NM-2006 after that NM-2011 and minimum seed yield, biological yield and harvest index were recorded in Azri-mung 2006 (Table 4). The seed yield is the interplay of yield components. The maximum seed yield in the early sown crop can be due to maximum emergence count, longer pods with more seeds and seed weight as compared to the other SD (Khattak et al., 2006; Ahmad et al., 2008). Likewise, the maximum biological yield was noticed in crop sown on $25^{\text {th }}$ April that can be due to maximum emergence count, longer pods with more seeds and seed weight as compared to the other SD. The cultivars also behaved differently for the seed and biological yield; NM-2006 had more seed and biological yield as compared to other cultivars owing to higher emergence count, longer pods with more seeds. Earlier Seijoon et al. (2000) and Singh et al. (2006) also noted the significant difference among cultivars for seed and biological yield owing to differences in the yield characters.

Table 4: Effect of different cultivars and sowing times on seed, biological yield and harvest index of mungbean crop.

\begin{tabular}{|c|c|c|c|}
\hline Cultivars & $\begin{array}{l}\text { Seed yield } \\
\left(\mathrm{kg} \mathrm{ha}^{-1}\right)\end{array}$ & $\begin{array}{l}\text { Biological } \\
\text { yield }\left(\mathrm{kg} \mathrm{ha}^{-1}\right)\end{array}$ & $\begin{array}{l}\text { Harvest } \\
\text { index (\%) }\end{array}$ \\
\hline Azri-Mung 2006 & $1029.22 \mathrm{C}$ & $3794.22 \mathrm{C}$ & 26.99B \\
\hline NM-2011 & 1130.11B & 4176.33B & 27.04B \\
\hline NM-2006 & $1279.67 \mathrm{~A}$ & $4373.11 \mathrm{~A}$ & $29.25 \mathrm{~A}$ \\
\hline $\mathrm{LSD} \leq 0.05 \mathrm{P}$ & 55.62 & 155.57 & 1.92 \\
\hline \multicolumn{4}{|l|}{ Sowing dates (SD) } \\
\hline $25^{\text {th }}$ April & $1300.22 \mathrm{~A}$ & $4439.56 \mathrm{~A}$ & $29.33 \mathrm{~A}$ \\
\hline $5^{\text {th }}$ May & $1163.56 \mathrm{~B}$ & 4142.44B & $28.09 \mathrm{AB}$ \\
\hline $15^{\text {th }}$ May & $975.22 \mathrm{C}$ & $3761.67 \mathrm{C}$ & 25.87B \\
\hline $\mathrm{LSD} \leq 0.05 \mathrm{P}$ & 82.49 & 166.02 & 2.67 \\
\hline \multicolumn{4}{|l|}{ Cultivars $\times$ SD } \\
\hline $\begin{array}{l}\text { Azri-Mung } 2006 \times 25^{\text {th }} \\
\text { April }\end{array}$ & $1195.00 \mathrm{bc}$ & 4046.67 & 29.54 \\
\hline 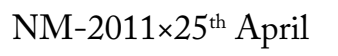 & $1282.00 \mathrm{~b}$ & 4418.00 & 29.09 \\
\hline NM-2006 $\times 25^{\text {th }}$ April & $1423.67 \mathrm{a}$ & 4854.00 & 29.36 \\
\hline $\begin{array}{l}\text { Azri-Mung } 2006 \times 5^{\text {th }} \\
\text { May }\end{array}$ & $1076.67 \mathrm{de}$ & 3887.67 & 27.74 \\
\hline NM-2011 $\times 5^{\text {th }}$ May & $1123.00 \mathrm{~cd}$ & 4191.00 & 26.84 \\
\hline NM-2006 $\times 5^{\text {th }}$ May & $1291.00 \mathrm{~b}$ & 4348.67 & 29.68 \\
\hline $\begin{array}{l}\text { Azri-Mung } 2006 \times 15^{\text {th }} \\
\text { May }\end{array}$ & $816.00 f$ & 3448.33 & 23.69 \\
\hline 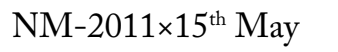 & $985.33 \mathrm{e}$ & 3920.00 & 25.19 \\
\hline 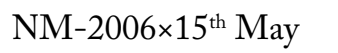 & $1124.33 \mathrm{~cd}$ & 3916.67 & 28.72 \\
\hline $\mathrm{LSD} \leq 0.05 \mathrm{P}$ & 96.34 & NS & NS \\
\hline
\end{tabular}

Means with different letters differed at $0.05 \mathrm{P}$ level.

\section{Conclusions and Recommendations}

The results depicted the significant impact of sowing dates and cultivars on the growth and productivity of mungbean crop. The sowing on $25^{\text {th }}$ April resulted in better growth, and seed yield compared to other sowing dates, however, sowing at $15^{\text {th }}$ caused a significant reduction in growth and yield of mungbean. Therefore, mungbean crop can be grown from $25^{\text {th }}$ April to $5^{\text {th }}$ May in rice-wheat crop system to obtain maximum yield from the mungbean.

\section{Novelty Statement}

The yield potential of different mungbean cultivars under different sowing dates was not fully explored. Thus this study was performed to determine the yield potential of different mungbean cultivars under different sowing dates.

\section{Author's Contribution}

Muhammad Umer Chattha and Imran Khan: Conceived and designed the experiment.

Maqsood Ahmad: Performed the experiment.

Maqsood Ahmad, Sadia Afzal and Muhammad

Faran: Data collection.

Muhammad Umer Chattha, Imran Khan, Muhammad Umair Hassan and Muhammad Talha Aslam: Writing original draft.

Muhammad Bilal Chattha, Faqir Hussain Anjum, Fiaz Hussain, Abdul Jabbar, Muhammad Sultan Ali Bazmi and Mahnoor Mehmood: Reviewing and editing.

Conflict of interest

The authors have declared no conflict of interest.

\section{References}

Ahmad, M.S.A., Hossain, M., Ijaz, S. and Alvi, A.K., 2008. Photosynthetic performance of two mungbean (Vigna radiata) cultivars under lead and copper stress. International Journal of Agriculture and Biology, 10: 167-172.

Almodares, A. and Darany, S.M.M.,2006. Effects of planting date and time of nitrogen application on yield and sugar content of sweet sorghum. Journal of Environmental Biology, 27(3): 601605.

Ali, R.I., Awan, T.H.M., Ahmad, A, Saleem, M.U. 
and Akhtar, M., 2012. Diversification of ricebased cropping systems to improve soil fertility, sustainable productivity and economics. Journal of Animal and Plant Science, 22: 108-112.

Ali, M. and Gupta, S., 2012. Carrying capacity of Indian agriculture: Pulse crops. Current Science, 102: 874-881.

Asghar, A., Chaudhry, A.M., Tanveer, A., 2006. Response of mung bean (Vagina radiate $\mathrm{L}$. genotypes to rhizobia culture. Pakistan Journal of Agriculture Science, 37: 1-2.

Aslam, M., Mahmood, I.A., Sultan, T., Ahmad, S., 2000. Inoculation approach to legume crops and their production assessment in Pakistan-A Review. Pakistan Journal of Biological Science, 2: 193-195. https://doi.org/10.3923/pjbs.2000.193.195

Aslam, M.M., Zeeshan, M., Irum, A., Hassan, M.U., Ali, S., Hussain, R., Ramzani, P.M.A. and Rashid, M.F., 2015. Influence of seedling age and nitrogen rates on productivity of rice (Oryza sativa L.): A Review. American Journal of Plant Sciences, 6: 1361-1369. https://doi. org/10.4236/ajps.2015.69135

Baddeley, J.A., Jones, S., Topp, C.F.E., Watson, C.A., Helming, J., and Stoddard, F.L., 2013. Biological nitrogen fixation (BNF) in Europe. Legume Future Report, 1: 5-11.

Barros, J.F., Carvalho, M., and Basch, G., 2004. Response of sunflower (Helianthus annuus L.) to sowing date and plant density under Mediterranean conditions. European Journal of Agronomy, 21: 347-356. https://doi.org/10.1016/j. eja.2003.10.005

Chattha, M.U., Hassan, M.U., Khan, I., Chattha, M.B., Ashraf, I., Ishque, W., Farooq, M.U., Usman, M. and Kharal, M., 2017a. Effect of different nitrogen and phosphorus fertilizer levels in combination with nitrogen and phosphorus solubilizing inoculants on the growth and yield of mung bean. Pakistan Journal of Life and Social Sciences, 15(1): 31-36.

Chattha, M.U., Khan, I., Hassan, M.U., Nawaz, M., Chattha, M.B., Ahamd, I., Khan, N.H., Usman, M., Kharal, M. and Khan, A.U., 2017b. Agronomic appraisal of amaranth accessions under semiarid conditions of Pakistan. Pakistan Journal of Life and Social Sciences, 15(3): 144149.

Chattha,M.U.,Hassan,M.U.,Barbanti,L., Chattha, M.B., Khan, I., Usman, M., Ali, A. and Nawaz, M., 2019. Composted sugarcane by-product press mud cake supports wheat growth and improves soil properties. International Journal of Plant Production, 13(3): 241-249. https://doi. org/10.1007/s42106-019-00051-x

Chattha, M.U., Hassan, M.U., Khan, I., Chattha, M.B., Aamer, M., Nawaz, M., Anjum, S.A., Ashraf, U. and Kharal, M., 2020. Impact of planting methods on biomass production, chemical composition and methane yield of sorghum cultivars. Pakistan Journal of Agricultural Sciences, 57(1): 43-51.

Hassan, M.U., Chattha, M.U., Mahmood, A. and Sahi, S.T., 2018a. Performance of sorghum cultivars for biomass quality and biomethane yield grown in semi-arid area of Pakistan. Environmental Science and Pollution Research, 25(13): 12800-12807. https://doi. org/10.1007/s11356-018-1575-4

Hassan, M.U., Chattha, M.U., Chattha, M.B., Mahmood, A. and Sahi, S.T., 2018b. Biomethane production from sorghum elite lines under the climatic conditions of Pakistan. Maydica, 63(1): 1-8.

Hassan, M.U., Chattha, M.U., Barbanti, L., Chattha, M.B., Mahmood, A., Khan, I. and Nawaz, M., 2019a. Combined cultivar and harvest time to enhance biomass and methane yield in sorghum under warm dry conditions in Pakistan. Industrial Crops and Products, 132: 8491. https://doi.org/10.1016/j.indcrop.2019.02.019

Hassan, M.U., Chattha, M.U., Chattha, M.B., Mahmood, A. and Sahi, S.T., 2019b. Chemical composition and methane yield of sorghum as influenced by planting methods and cultivars. The Journal of Animal and Plant Sciences, 29(1): 251-259.

Hassan, M.U., Chattha, M.U., Khan, I., Chattha, M.B., Barbanti, L., Aamer, M., Iqbal, M.M., Nawaz, M., Mahmood, A., Ali, A. and Aslam, M.T., 2020a. Heat stress in cultivated plants: Nature, impact, mechanisms, and mitigation strategies. A review. Plant Biosystems, 155: 211234. https://doi.org/10.1080/11263504.2020.172798 7

Hassan, M.U, Aamer, M., Chattha, M.U, Haiying, T., Shahzad, B., Barbanti, L., Nawaz, M., Rasheed, A., Afzal, A., Liu, Y. and Guoqin, H., $2020 \mathrm{~b}$. The critical role of zinc in plants facing the drought stress. Agriculture, 10(9): 396. https://doi.org/10.3390/agriculture10090396

Hassan, M.U., Chattha, M.U., Barbanti, L., 
Mahmood, A., Chattha, M.B., Khan, I., Mirza, S., Aziz, S.A., Nawaz, M. and Aamer, M., 2020c. Cultivar and seeding time role in sorghum to optimize biomass and methane yield under warm dry climate. Industrial Crops and Products, 145: 111983. https://doi.org/10.1016/j. indcrop.2019.111983

Homer, D.C. and Pratt, P.F., 1961. Methods of analysis for soils, plants and waters. Davis: University of California, Davis.

Hunt, R., 1978. Plant growth analysis. The institute Biology's studies in Biology. Edward Arnold (Pub) Ltd, London, 96: 8-38.

Jan, A., F.H. Taj., Khan, I.A. and Khan, N., 2002. Effect of sowing dates on yield and yield components of Mashbean varieties. Asian Journal of Plant Science, 10: 622-624. https://doi. org/10.3923/ajps.2002.622.624

Kassie, M., 2011. Economic and environmental benefits offorage legume-cereal intercropping in the mixed farming system: A case study in west Gojam, Ethiopia. Addis Ababa, Ethiopia: EDRI.

Khattak, G.S.S., Ashraf, M., Saeed, I. and Alam, A., 2006. A new high yielding mungbean (Vigna radiate $L$.) variety" Ramzan" for the agro climatic conditions of NWFP. Pakistan Journal of Botany, 38: 301-309.

Knezevic, S.Z., Evans, S.P., Blankenship, E.E., VanAcker, R.C. and Lindquist, J.L., 2002. Critical period for weed control: The concept and data analysis. Weed Science, 50:773-786. https:// doi.org/10.1614/0043-1745(2002)050[0773:CPFW CT]2.0.CO;2

Mondal, M.M.A., 2004. Performance of four summer mungbean varieties at Rangpur Zone of Bangladesh. Journal of Nuclear Agriculture and Biology, 19: 145-149.

Muhsin, M., Nawaz, M., Khan, I., Chattha, M.B., Khan, S., Aslam, M.T., Iqbal, M.M., Amin, M.Z., Ayub, M.A., Anwar, U. and Hassan, M.U., 2021. Efficacy of seed size to improve field performance of wheat under late sowing conditions. Pakistan Journal of Agricultural Research, 34(1):247-253.https://doi.org/10.17582/ journal.pjar/2021/34.1.247.253

Reddy, A.A., 2009. Pulses production technology: Status and way forward. Economic and Political Weekly, 44: 73-80. https://doi.org/10.2139/ ssrn. 1537540

Rao, S.S., Patil, J., Prasad, P.V.V., Reddy, D.C.S., Mishra, J.S., Umakanth, A.V., Reddy, B.V.S., and Kumar, A.A., 2012. Sweet sorghum planting effects on stalk yield and sugar quality in semi-arid tropical environment. Agronomy Journal, 105: 1458-1465. https://doi.org/10.2134/ agronj2013.0156

Sarkar, M.A.R., Kabir, M.H., Begum, M. and Salam, M.A., 2004. Yield performance of mungbean as affected by planting date, variety and plant density. Journal of Agronomy, 3(1): 18-24. https://doi.org/10.3923/ja.2004.18.24

Seijoon, P., Wookhan, K. and Rakehun, S., 2000. Influence of different planting times on harvest index and yield determination factors in soybean. Korean Journal of Crop Science, 45: 97102.

Siddique, M., Malik, M.F.A. and Awan, S.I., 2006. Genetic divergence, association and performance evaluation of different genotypes of mungbean (Vigna radiata). International Journal of Agriculture and Biology, 8: 793-795.

Singh. J., Mathur, N.., Bohra, S., Bohra, A. and Vyas, A., 2006. Comparative performance of Mungbean (Vigna radiata L.) varieties under rainfed condition in Indian Thar desert.American Journal of Agriculture and Environmental Science, 1: 48-50.

Soomro, N.A., 2003. Response of mungbean genotypes to different dates of sowing in kharif season under rainfed condition. Asian Journal of Plant Science, 2: 377-379. https://doi.org/10.3923/ ajps.2003.377.379

Steel, R.G.D., Torrie, J.H. and Dickey, D.A., 1997. Principles and procedures of statistics: A biometric approach, 3rd edn. McGraw Hill Book Co. Inc., New York.

Timsina, J. and Connor, D.J., 2001. Productivity and management of rice-wheat cropping systems: issues and challenges. Field Crops Research, 69: 93-132. https://doi.org/10.1016/ S0378-4290(00)00143-X

Vega, A.J. and Hall, A.J., 2002. Effects of planting date, genotype, and their interactions on sunflower yield. Crop Science, 42: 1191-1201. https://doi.org/10.2135/cropsci2002.1191

Watson, D.J., 1947. Comparative physiological studies in the growth of field crops. I: variation in net assimilation rate and leaf area between species and varieties, and within and between years. Annals of Botany, 11: 41-76. https://doi. org/10.1093/oxfordjournals.aob.a083148

Wiedenfeld, B. and Matocha, J., 2010. Planting 
date, row configuration and plant population effects on growth and yield of dryland sorghum in subtropical South Texas. Archives of Agronomy and Soil Science, 56(1): 39-47. https://doi. org/10.1080/03650340902922696

Yan-sheng, L., Qiu-ying, Z., Qing, S.G., Herbert, J. and Hashemi, A., 2010. Influence of sowing date on phonological stages, seed growth and marketable yield of four vegetable soybean cultivars in North-eastern USA. African Journal of Agriculture Research, 5: 2556-2562.

Yoldas, F. and Esiyok, D., 2007. Effects of sowing dates and cultural treatments on growth, quality and yield of processing beans. Pakistan Journal of Biological Science, 10: 2470-2474. https://doi. org/10.3923/pjbs.2007.2470.2474

Zamir, S.I., Haq, I.U., Chattha, M.U., Hassan, M.U., Khan, I. Chattha, M.B., Saeed, N., Iqbal, M.M., Ayub, M.A. and Rehman, A., 2020. Harvesting at milking stage along with urea and molasses addition improved the quality and fermentation characteristics of corn silage. International Journal of Agriculture and Biology, 23:253-258. 